УДК 636.2.082:575.1:591.11

DOI 10.32900/2312-8402-2020-124-15-23

\title{
GENETIC DIVERSITY OF SIMMENTAL CATTLE LINES BY POLYMORPHIC BLOOD GROUP SYSTEMS
}

\author{
Rossokha V. I., ph. d., sen. research., \\ Drobiazko O. V., research., \\ Boyko Y. A., ph. d., sen. research., \\ Tur G. N., ph. d., sen. research., \\ Oliinychenko Y. K., ph. d., sen. research., \\ Zaderikhina O. A., research., \\ Brovko O. V., research. \\ Insitute of Animal Science of NAAS
}

Marking the cattle populations by individual genes and gene complexes creates new opportunities for the development of selection when genetic methods aim to prevent the decrease of the populations' gene variability. The article reveals the studies of the genetic structure of the Simmental cattle population, PAT breeding facility "Chervoniy Veleten" for erythrocyte antigens of 9 genetic systems ( $A, B, C, F, J, L, M, S, Z)$; linear affiliation of animals was taken into account.

Animal erythrocyte antigens were determined by hemolysis reaction using monospecific sera - reagents. It is established that the spectrum of certain antigens is specific for Simmental cattle. The high frequency of antigenic factors $G_{2}, T_{2}, E_{3}{ }^{\prime}, G^{\prime}, I^{\prime}, O^{\prime}, Q^{\prime}$, $B^{\prime \prime}(q=0,364-0,636)$ let us identify allele markers inherent in Simmental cattle: $B G K E^{\prime} G^{\prime} O^{\prime} Q^{\prime}, B G K E^{\prime} O^{\prime}, B G O^{\prime}, G_{2} O_{2} Y_{2}$, as well as $O Q^{\prime}, O I^{\prime} Q^{\prime}, T V^{\prime} P^{\prime}$.

The analysis of the of the most numerous factory lines (Neolit, Lavra, Zorkiy, Biser, Lascar) was carried out. It was shown that the markers of the Neolit line can be considered as the alleles: $B^{O I^{\prime} Q^{\prime}}(q=0.2931)$ and $B^{\text {OTG'K}}(q=0.2392)$, Lavra $-B^{\text {BIA } K^{\prime}}(q$ $=0.1863)$ and $B^{O^{\prime}}(q=0.2500)$, Zorkiy $-B^{B G O}{ }^{\prime}(q=0.1325)$ and $B^{b}$, Biser $-B^{O{ }^{\prime} Q^{\prime}}(q=$ $0.2246)$ and $B^{G /}(q=0.1920)$, Lascara - $B^{B G K E^{\prime} G O^{\circ}} Q^{\prime}(q=0.1405)$ and $B^{O^{\prime}}(q=0.2735)$.

It was found, that alleles EAB, which are more common for Laurel and Lascar lines $(K v=32.04 \%)$ are marked by the most similarities in the alleles of the EAB - blood group system, the highest values of the difference coefficient are characteristic of the Neolit - Lascar and Neolit - Laurel lines (55.66\% and $54.86 \%$ respectively), the most differentiated was the Neolit line $\left(K_{v}\right.$ ser. $\left.=49.48 \%, d_{\text {ser. }}=0.332\right)$. Detection of interlinear differences in related groups of Simmental cattle allows preliminary prediction, correction and plan the animal selection for factory mating.

Key words: erythrocyte antigens, polymorphic blood group systems, antigen frequency, genetic differentiation, cattle, Simmental breed, line.

The provision of the food market with high-quality domestic products in sufficient quantities is impossible without the intensification of animal husbandry, where effective selection plays an important role. Selection processes occurring in herds and populations due to migration, as well as mutations in genes that constantly occur, change their genotypic structure. One of the ways to control these processes is complementing Immunogenetics into selection process [1-3].

Detecting markers in animal blood allows us to reveal the mechanism of inheritance of parent genotype, and also the alleles of ancestors on generations of descendants and to develop more advanced approaches in the selection process. Knowledge of genotype by blood groups of breed stock and uterine livestock allows purposeful mating 
of individuals to consolidate new valuable breeding qualities in offspring, as well as to accumulate in the herd those genotypes which are positively combined with economically useful traits. $[4,5]$.

Information on the genetic structure of polymorphic traits, which include blood groups, is used to assess the degree of genetic relatedness or differentiation of the studied animal populations. Thus, the labeling of cattle populations by individual genes and gene complexes, as well as determining on their basis the genotypic structure and level of diversity, both structural units, and populations as a whole, creates prerequisites for the development of selection - genetic approaches to prevent narrowing of the gene pool and methods of control and marking of selection processes [6].

Selection work under constant genetic control creates the preconditions for maintaining a high degree of genetic diversity of genes and gene complexes that determine the adaptability, manifestation of productive traits and unique features of these breeds. Simmental cattle are one of the oldest breeds in the world. The beginning of the formation of this breed can be attributed to the Middle Ages, but as a cultural breed, it was formed much later - in the late nineteenth - early nineteenth centuries. Purposeful breeding work with Simmentals had a significant improvement in recent decades [2, 7].

The origin of the Simmental breed in Ukraine dates back to the 70s of the XIX century. The cattle was mainly imported from Sweden, and crossed with Gray Ukrainian cattle. In modern herds, there are animals of several production types: dairy, dairymeat, and meat-dairy direction of productivity. In the $70 \mathrm{~s}$ of the twentieth century (in 1974) the percentage of a Simmental breed among other breeds in Ukraine was $37.4 \%$. The cattle was bred in 17 regions of Ukraine. Due to the strength of the constitution and the relative unpretentiousness of the environment, Simmentals were most common in the area of beet sowing, which was combined with intensive grain farming. Simmental cattle have traditionally been characterized by a relatively thorough breeding facility. Back in 1987, there were 22 breeding facilities and 12 breeding facilitys, the average productivity of cows was 4435 and $3538 \mathrm{~kg}$, respectively. In many herds, this figure exceeded to $5,000 \mathrm{~kg}[4,8-10]$.

Purposeful breeding work with the Simmental cattle breed in Ukraine began much earlier than with many other breeds. This contributed to the fact that many valuable lines were bred, for instance, in the Trostyanets stud farm - the lines of Bystrogo, Bogatyr, Vakhter, Sidonis, Hetman, Mergel, Askold, Signal, Micrometr, Mars, Symmetrichniy, Naliota, Vizova, Vernogo; "Terezine" - the lines of Herodes, Alrum, Zipper, Codex, Bilyanka; "Hmilovik" - the lines of Lord, Faust, Fidel; in the breeding facility "Chervoniy Veleten" - 129 lines Biser, Taman, Lavra, Neolit; in the breeding facility "Matusovoe" - the Moha line; "Shamrayevsky" - Lebed lines; in the "Verkhnyatsky" breeding facility - the Apelsin line; in the area of the Zolotonosha Interdistrict Association (MRPO) and the former Helmyazivsky DPR - the lines of Ekzemplar, Kagal, Jesuit, Perun, Fastun, Kimer, Bolonda, Belnar and others. These are only those lines that were bred and used in Ukrainian farms [11].

Nowadays in Ukraine there is a complete decline of the livestock industry, so the necessary measures must be taken to urgently revive it and state support. Preservation of the gene pool of the breed and the main lines, when the Simmental one, is one of the priority tasks. Therefore, the evaluation of cattle lines for the immunogenetic markers of blood groups can increase the effect of selection and turns out to be an urgent task. Currently, the main method of working with the breed is breeding within the lines $[12,13]$. 
Our work aimed to study the genetic structure of the population of Simmental cattle PJSC breeding facility "Chervoniy Veleten", taking into account the linear affiliation of animals.

Materials and methods of research. The research was based on the results of testing for erythrocyte antigens of the Simmental cattle of domestic selection (PJSC "breeding facility "Chervoniy Veleten ") of Kharkiv region. The structure of the five most numerous factory lines was analyzed.

Erythrocyte antigens of animals were determined by hemolysis reaction using monospecific sera - reagents. 48 erythrocyte antigens controlled by 9 polymorphic blood group systems (A, B, C, F, J, L, M, S, Z) of cattle were taken into account. Statistical analysis was performed by conventional methods.

Research results. The results of the attestation of breeding animals of PJSC breeding facility "Chervoniy Veleten" by blood groups for the period 2010 - 2016 were used. The analysis of breeding animals of PJSC breeding facility "Chervoniy Veleten" by blood groups showed that in the examined group of animals found with varying frequency almost all antigens (Fig. 1).

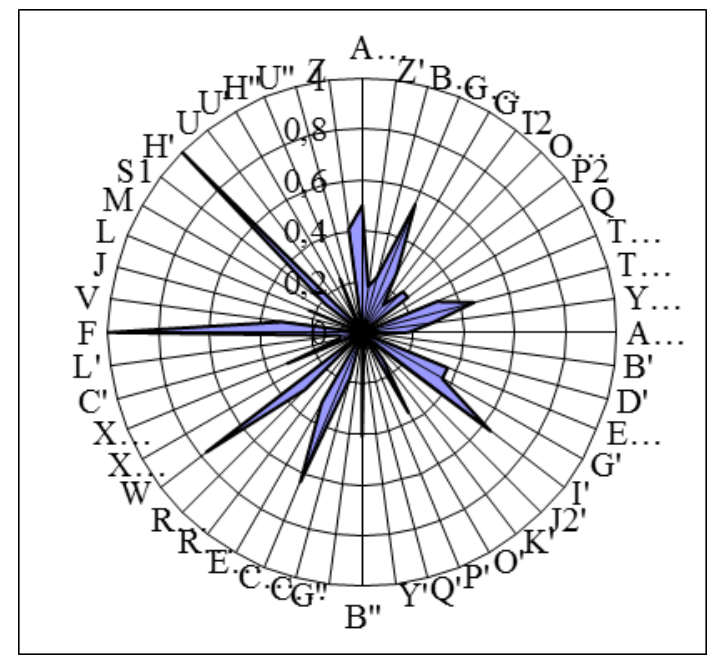

$\mathrm{An}=0,2067$

$\mathrm{AnB}=0,2727$

$\mathrm{AnC}=0,2498$

$\mathrm{AnS}=0,2528$

\section{Figure 1 - Immunogenetic profile of Simmental cattle PJSC Breeding facility «Chervoniy Veleten"}

It was established, that in EAB system has a high frequency of antigens $\mathrm{G}_{2}, \mathrm{~T}_{2}$, $\mathrm{E}_{3}{ }^{\prime}, \mathrm{G}^{\prime}, \mathrm{I}^{\prime}, \mathrm{O}^{\prime}, \mathrm{Q}^{\prime}, \mathrm{B}^{\prime \prime}(\mathrm{q}=0,364-0,636)$; in the system EAC - antigens $\mathrm{C}_{2}$ and $\mathrm{W}$ $(\mathrm{q}=0,636-0,773)$, EAS-system is mainly represented by $\mathrm{H}^{\prime}(\mathrm{q}=1,000)$ antigen. Antigens EAB-systems - $\mathrm{B}_{2}, \mathrm{G}_{3}, \mathrm{O}_{2}, \mathrm{P}_{2}, \mathrm{Y}_{2}$; EAC-systems - E, $\mathrm{R}_{2}, \mathrm{X}_{2}$; EAS-systems - $\mathrm{S}_{1}, \mathrm{H}^{\prime \prime}$ have frequency $0,227-0,318$. Antigenic erythrocyte factors $\mathrm{B}^{\prime}, \mathrm{J}_{2}^{\prime}, \mathrm{Y}^{\prime}$ (EAB-system); $\mathrm{U}, \mathrm{U}^{\prime}$ (EAS- system) happen in 4-5\% cases. Antigenic erythrocyte factors Q, D', $\mathrm{P}^{\prime}, \mathrm{G}^{\prime \prime}$, $\mathrm{J}, \mathrm{M}, \mathrm{U}^{\prime \prime}$ phenotypically were not detected. It is established that the spectrum of certain antigens is characteristic of Simmental cattle. High frequency of antigenic factors $G_{2}$, $\mathrm{T}_{2}, \mathrm{E}_{3}{ }^{\prime}, \mathrm{G}^{\prime}, \mathrm{I}^{\prime}, \mathrm{O}^{\prime}, \mathrm{Q}^{\prime}, \mathrm{B}^{\prime \prime}(\mathrm{q}=0,364-0,636)$ gives reason to identify alleles markers characteristic of Simmental cattle: BGKE/G/O/Q/, BGKE/O/, BGO/, $\mathrm{G}_{2} \mathrm{O}_{2} \mathrm{Y}_{2}$, а також $\mathrm{OQ}^{\prime}, \mathrm{OI}^{\prime} \mathrm{Q}^{\prime}, \mathrm{TB}^{\prime} \mathrm{P}^{\prime}$, and also, $\mathrm{OQ}^{\prime}, \mathrm{OI}^{\prime} \mathrm{Q}^{\prime}, \mathrm{TB}^{\prime} \mathrm{P}^{\prime}$.

The monitoring of breed-linear genetic markers of Simmental breed was conducted in the groups of Laurel, Biser, Neolit, Lascara, Zorkiy lines; it which allowed to determine interlinear differences and investigate the nature of marker inheritance in related groups of Simmental cattle, which allows preliminary prediction and correction of animals for further factory mating. 
Thus, in the related Neolit group $(n=232) 13$ alleles of the B-system of blood groups with frequencies $q=0.0129-0.2931$ were found (Table 1). Other detected alleles occur with a frequency of $q \geq 0.010$, therefore they were not used in the analysis. Markers of this line are the allele $\mathrm{B}^{\text {OI'Q' }}(\mathrm{q}=0.2931)$ and the other is $\mathrm{B}^{\text {OTG'K}^{\prime}}(\mathrm{q}=$ 0.2392). 14 alleles with frequencies $q=0.0147-0.2500$ were detected along the Lavra line $(\mathrm{n}=102)$. There are seven alleles in which the frequencies do not exceed 0.0100 . The marker alleles of this line are the $\mathrm{B}^{\mathrm{BIA}^{*} \mathrm{~K}^{\prime}}$ allele $(\mathrm{q}=0.1863)$ and the $\mathrm{B}^{\mathrm{O}^{\prime}}$ allele $(\mathrm{q}=$ $0.2500)$.

Table 1.

Distribution of frequencies of alleles-markers in the system of blood groups of Simmental cattle lines PJSC Breeding facility "Chervoniy Veleten"

\begin{tabular}{|c|c|c|c|c|c|}
\hline \multirow{2}{*}{ Alleles } & \multicolumn{5}{|c|}{ Lines } \\
\cline { 2 - 6 } & Neolita & Lavra & Zorkogo & Biser & Laskara \\
\hline $\mathrm{B}$ & 0.0928 & 0.0735 & $\mathbf{0 . 1 7 0 0}$ & 0.0326 & 0.0906 \\
\hline $\mathrm{BGO}$ & - & - & - & 0.0217 & 0.0178 \\
\hline $\mathrm{BGKO}^{\prime}$ & - & - & - & 0.0145 & - \\
\hline $\mathrm{BGKE}^{\prime} \mathrm{G}^{\prime} \mathrm{O}^{\prime} \mathrm{Q}^{\prime}$ & 0.0474 & 0.0343 & 0.0450 & 0.0652 & $\mathbf{0 . 1 4 0 5}$ \\
\hline $\mathrm{BGG}^{\prime} \mathrm{K}^{\prime}$ & 0.0388 & - & 0.0100 & - & - \\
\hline $\mathrm{BGO}^{\prime}$ & - & 0.0147 & $\mathbf{0 . 1 3 2 5}$ & 0.0109 & 0.0219 \\
\hline $\mathrm{BIQ}^{\prime}$ & - & - & 0.0125 & - & - \\
\hline $\mathrm{BIA}^{\prime} \mathrm{K}^{\prime}$ & 0.0151 & $\mathbf{0 . 1 8 6 3}$ & 0.0350 & 0.0833 & 0.0469 \\
\hline $\mathrm{BIOK}^{\prime}$ & - & 0.0245 & - & - & - \\
\hline $\mathrm{BIK}^{\prime}$ & - & - & 0.0175 & - & - \\
\hline $\mathrm{IY}_{2} \mathrm{I}^{\prime}$ & - & - & 0.0175 & 0.0217 & 0.0313 \\
\hline $\mathrm{II}^{\prime}$ & - & 0.0147 & - & - & - \\
\hline $\mathrm{O}$ & - & - & 0.0150 & 0.0125 & 0.0125 \\
\hline $\mathrm{OTG}^{\prime} \mathrm{K}^{\prime}$ & $\mathbf{0 . 2 3 9 2}$ & 0.0735 & 0.0625 & 0.0978 & 0.0375 \\
\hline $\mathrm{OTI}^{\prime} \mathrm{K}^{\prime}$ & - & - & - & 0.0217 & - \\
\hline $\mathrm{OI}^{\prime} \mathrm{Q}^{\prime}$ & $\mathbf{0 . 2 9 3 1}$ & 0.0637 & 0.1025 & $\mathbf{0 . 2 2 4 6}$ & 0.0781 \\
\hline $\mathrm{A}^{\prime} \mathrm{B}^{\prime} \mathrm{D}^{\prime} \mathrm{G}^{\prime}$ & 0.0151 & 0.0196 & 0.0150 & 0.0217 & 0.0125 \\
\hline $\mathrm{Y}_{2} \mathrm{~B}^{\prime} \mathrm{E}^{\prime} \mathrm{G}^{\prime}$ & - & 0.0196 & - & - & - \\
\hline $\mathrm{D}^{\prime} \mathrm{G}^{\prime} \mathrm{I}^{\prime}$ & 0.0345 & 0.0196 & 0.0175 & 0.0145 & - \\
\hline $\mathrm{E}_{2}^{\prime} \mathrm{I}^{\prime}$ & 0.0151 & - & - & - & - \\
\hline $\mathrm{G}^{\prime}$ & 0.0280 & 0.0735 & 0.0650 & $\mathbf{0 . 1 9 2 0}$ & 0.0469 \\
\hline $\mathrm{G}^{\prime} \mathrm{I}^{\prime}$ & 0.0129 & 0.0294 & 0.0100 & - & - \\
\hline $\mathrm{I}^{\prime} \mathrm{O}^{\prime}$ & 0.0172 & - & - & - & - \\
\hline $\mathrm{O}^{\prime}$ & 0.0754 & $\mathbf{0 . 2 5 0 0}$ & 0.1325 & 0.0906 & $\mathbf{0 . 2 7 3 5}$ \\
\hline
\end{tabular}

In the group of animals which make the Zorkiy line $(n=200), 16$ alleles were identified with a frequency of $\mathrm{q}=0.0100-0.1700$ and four with a frequency of $\mathrm{q} \geq$ 0.0100 . The markers of this line in the B-system of blood groups after the corresponding analysis include the allelomorph $\mathrm{B}^{\mathrm{BGO}}(\mathrm{q}=0.1325)$ and the "silent" allele $\mathrm{B}^{\mathrm{b}}$. In Biser line $(n=138) 15$ alleles with frequencies $q=0.0109-0.2246$ were identified; only one allelomorph was identified with the frequency $\mathrm{q}=0.0100$. Markers of this group of animals can include alleles $\mathrm{B}^{\text {OrQ }}(\mathrm{q}=0.2246)$ and $\mathrm{B}^{\mathrm{G} /}(\mathrm{q}=0.1920)$. According to the related group of the Lascar line, there are 12 alleles with frequencies $q=0.0125-0.2735$, 
in this group of animals ten allelomorphs occur with a frequency of less than 0.0100 . The alleles-markers of the Lascar line are the allelomorphs $B^{\mathrm{GKE}^{\prime} \mathrm{GO}} \mathrm{O}^{\prime}(\mathrm{q}=0.1405)$ and $\mathrm{B}^{\mathrm{O}^{\prime}}(\mathrm{q}=0.2735)$.

The analysis of genetic differentiation of Simmental cattle lines of PAT Breeding facility "Chervoniy veleten" was carried out (tab. 2).

Table 2.

\section{Indicators of differentiation between Simmental cattle lines of PJSC breeding facility "Chervoniy Veleten" of Kharkiv region}

\begin{tabular}{|l|c|c|c|c|c|}
\hline \multicolumn{1}{|c|}{ Lines } & $\mathbf{1}$ & $\mathbf{2}$ & $\mathbf{3}$ & $\mathbf{4}$ & $\mathbf{5}$ \\
\hline 1. Neolita & - & 54.86 & 46.90 & 40.48 & 55.66 \\
\hline 2. Lavra & 0.383 & - & 40.38 & 45.51 & 32.04 \\
\hline 3. Zorkogo & 0.314 & 0.254 & - & 43.58 & 36.53 \\
\hline 4. Biser & 0.255 & 0.288 & 0.269 & - & 45.46 \\
\hline 5. Laskara & 0.376 & 0.194 & 0.225 & 0.302 & - \\
\hline \multicolumn{5}{|l}{} \\
\hline Mean $\mathrm{K}_{\mathrm{v}}$ & 49.48 & 43.20 & 41.85 & 43.76 & 42.42 \\
\hline Mean d & 0.332 & 0.280 & 0.266 & 0.278 & 0.274 \\
\hline
\end{tabular}
diagonal

Notes: coefficients of difference (Kv\%) - above the diagonal, Euclidean distance (d) - below the

The smallest differences were recorded between animals belonging to the Laurel and Lascar lines $(\mathrm{Kv}=32.04 \%)$. The highest values of coefficients of difference are characteristic of the Neolit - Lascar and Neolit - Lavra lines and are 55.66\% and $54.86 \%$, respectively. A similar situation is observed when comparing the Euclidean distance. The most differentiated are the animals of the Neolit line $\left(\mathrm{K}_{\mathrm{v} \text { ser. }}=49.48 \%, \mathrm{~d}_{\text {ser. }}\right.$. $=0.332$ ) against $41.85 \%$ and 0.266 for the animals of the Zorkiy line.

\section{Conlusions:}

1. The analysis of breeding animals of Simmental breed PJSC breeding facility "Chervoniy Veleten" by blood groups showed a high frequency of antigenic factors $\mathrm{G}_{2}$, $\mathrm{T}_{2}, \mathrm{E}_{3}^{\prime}, \mathrm{G}^{\prime}, \mathrm{I}^{\prime}, \mathrm{O}^{\prime}, \mathrm{Q}^{\prime}, \mathrm{B}^{\prime \prime}(\mathrm{q}=0,364$ - 0,636), which gives the opportunity to identify allele markers inherent in Simmental cattle: $\mathrm{BGKE}^{\prime} \mathrm{G}^{\prime} \mathrm{O}^{\prime} \mathrm{Q}^{\prime}, \mathrm{BGKE}^{\prime} \mathrm{O}^{\prime}, \mathrm{BGO}^{\prime}, \mathrm{G}_{2} \mathrm{O}_{2} \mathrm{Y}_{2}$, $\mathrm{OQ}^{\prime}, \mathrm{OI}^{\prime} \mathrm{Q}^{\prime}, \mathrm{TB}^{\prime} \mathrm{P}^{\prime}$.

2. The spectrum of immunogenetic markers of different linear affiliation (Neolitha, Lavra, Zorkiy, Biser, Lascar) is revealed.

3. It is shown that the markers of the Neolit line can be considered the allele $\mathrm{B}^{\text {OI'Q }^{\prime}}(\mathrm{q}=0,2931)$ and $\mathrm{B}^{\mathrm{OTG}^{\prime} \mathrm{K}^{\prime}}(\mathrm{q}=0,2392)$, Lavra $-\mathrm{B}^{\mathrm{BIA}^{\prime} \mathrm{K}^{\prime}}(\mathrm{q}=0,1863)$ and $\mathrm{B}^{\mathrm{O}}(\mathrm{q}=$ $0,2500)$, Zorkiy $-\mathrm{B}^{\mathrm{BGO}}(\mathrm{q}=0,1325)$ and $\mathrm{Bb}$, Biser $-\mathrm{B}^{\text {OrQ }}(\mathrm{q}=0,2246)$ and $\mathrm{B}^{\mathrm{G} /}(\mathrm{q}=$ $0,1920)$, Laskara - $\mathrm{B}^{\text {BGKE 'GÒ' } Q^{\prime}}(\mathrm{q}=0.1405)$ and $\mathrm{B}^{\mathrm{O}^{\prime}}(\mathrm{q}=0.2735)$.

4. The differentiation of Simmental cattle lines of PJSC breeding facility "Chervoniy Veleten" of Kharkiv region according to alleles of EAB - blood group system is estimated and it is established that the lines of Laurel and Lascar are the most similar $\left(\mathrm{K}_{\mathrm{v}}=32.04 \%\right)$, the highest values of coefficient of difference are characteristic for Neolit - Lascar and Neolit - Lavra lines (55.66\% and 54.86\%), the most differentiated is the Neolit line $\left(\mathrm{K}_{\mathrm{v} \text { ser. }}=49.48 \%, \mathrm{~d}_{\text {ser. }}=0.332\right)$.

5. Detection of interlinear differences in related groups of Simmental cattle by polymorphic blood group systems indicates the possibility of using these genetic markers for preliminary prediction, correction and planning of animal selection for factory mating. 


\section{Бібліографічний список}

1. Подоба Б. Є., Бородай І. С., Овчарук С. В. Імуногенетичний моніторинг у селекційних процесах створення та вдосконалення порід сільськогосподарських тварин. Розведення і генетика тварин : міжвідом. темат. наук. зб. / Інститут розведення і гентики тварин ім. М. В. Зубця. Київ, 2007. № 41. С. 171-180.

2. Prohorov I. P., Kalmykova O. A. Growth and Development Patterns of the Skeleton in Simmental and Cross Young Beef Bulls. Russian Agricultural Science. 2002. № 46. P. 295-299. DOI 10.3103/S1068367420030155

3. Копилов К. В., Заблудовський Є. Є. Генетичний моніторинг при збереженні племінних ресурсів тварин. Розведення і генетика тварин : міжвідом. темат. наук. зб. / Інститут розведення і гентики тварин ім. М. В. Зубця. Київ, 2008. № 42. C. 119-125.

4. Pochukalin, A. Y., Rizun, O. V., Priyma, S. V. 2017. Monitoring of the Simmental breed in Ukraine. Animal Breeding and Genetics. 2017. № 53. P. 179-184. DOI 10.31073/abg.53.24

5. Сердюк Г. Н., Каталупов А. Г. Группы крови сельскохозяйственных животных и эффективность их использования в селекции. Теоретический и научно-практический журнал Зоотехния. Москва, 2008. №8. С. 8-11.

6. Подоба Б. С., Бірюкова О. Д., Кухтіна К. В. Імуногенетична оцінка специфіки порід у системі генетичного моніторингу біорізноманіття. Вісник аграрної науки Причорномор’я /Миколаїв. держ аграр. ун-т. Миколаїв, 2012. № 12. C. $43-47$.

7. Шаталина О. С. Ассоциации между группами крови и репродуктивными показателями у крупного рогатого скота. Сельскохозяйственная биология. 2018. № 2. C. 30-47. DOI 10.15389/AGROBIOLOGY.2018.2.309RUS

8. Баранова Н. С., Баранов А. В., Подречнева И. Ю. Генетические особенности селекции высокопродуктивных коров заводских семейств костромской породы. Вестник АПК Верхневолжья. Ярославль, 2017. № 1 (37). С. 36-41.

9. Федорович В. В., Оріхівський Т. В., Бабік Н. П., Федорович С. І., Oceредчук Р. С. Характеристика корів симентальської породи за господарськи корисними ознаками в умовах Львівщини. Науковий вісник Львівського начіонального університету ветеринарної медицини та біотехнологій імені С.3. Гжищького. Львів, 2016. № 2 (67). С. 255-260. DOI 10.15421/NVLVET6756

10. Рижук С. М. Теоретико-методологічні та науково-організаційні аспекти створення симентальської породи великої рогатої худоби (історичний аспект). Вісник Національного технічного університету "ХПI". Харків, 2014. № 59. C. $124-129$.

11. Araujo F. R., Vieira D. A., Santos D. J. Population structure of Simmental beef cattle using pedigree analysis. Trop Animal Health Production. 2020. № 52. P. 1513-1517. DOI.ORG 10.1007/s11250-019-02102-x

12. Perisic P., Skalicki Z., Petrovic M. M. Simmental cattle breed in different production systems. Biotechnology in Animal Husbandry. 2009. № 25. P. 315-326. DOI 10.2298/BAH0906315P.

13. Gotza B., Luntza J., Robeisa C., Edela R., Emmerlinga J., Buitkampa H., Anzenbergera J. Simmental cattle - Current state of the breeding program. Livestock Science. 2015. № 179. P. 80-85.

\section{References}

1. Podoba, B. Ye. Borodai, I. S., \& Ovcharuk, S. V. (2007). Imunohenetychnyi monitorynh u selektsiinykh protsesakh stvorennia ta vdoskonalennia porid silskohospo- 
darskykh tvaryn [Immunogenetic monitoring in selection processes of creation and improvement of livestock animals]. Rozvedennia i henetyka tvaryn-Animal Breeding and Genetics. Kyiv, 41, 171-180 [in Ukrainian].

2. Prohorov, I. P., \& Kalmykova, O. A. (2002). Growth and Development Patterns of the Skeleton in Simmental and Cross Young Beef Bulls. Russian Agriculture Science, 46, 295-299. DOI 10.3103/S1068367420030155

3. Kopylov, K. V. \& Zabludovskyi, Ye. Ye. (2008). Henetychnyi monitorynh pry zberezhenni pleminnykh resursiv tvaryn [Genetic animal monitoring while conserving breeding resources]. Rozvedennia $i$ henetyka tvaryn - Animal Breeding and Genetics. Kyiv, 42, 119-125 [in Ukrainian].

4. Pochukalin, A. Y., Rizun, O. V., \& Priyma, S. V. (2017). Monitoring of the Simmental breed in Ukraine. Animal Breeding and Genetics, 53, 179-184. DOI 10.31073/abg.53.24

5. Serdyuk, G. N., \& Katalupov, A. G. (2008). Gruppy krovi sel'skohozyajstvennyh zhivotnyh i effektivnost' ih ispol'zovaniya v selekcii [Blood groups of farm animals and efficiency of their use in selection]. Zootekhniya-Zootechnology. Moscow, 8, 8-11 [in Russian].

6. Podoba, B. Ye. Biriukova, O. D., \& Kukhtina, K. V. (2012). Imunohenetychna otsinka spetsyfiky porid $u$ systemi henetychnoho monitorynhu bioriznomanittia [Immunogenetic assessment of breed specificity in the system of genetic monitoring of biodiversity]. Visnyk ahrarnoi nauk of Prichornomorya - Ukrainian Black Sea region agrarian science. Mykolayiv, 12, 43-47 [in Ukrainian].

7. Shatalina, O. S. (2018). Associacii mezhdu gruppami krovi i reproduktivnymi pokazatelyami u krupnogo rogatogo skota [Associations between blood groups and reproductive indices in cattle]. Selskohozyajstvennaya Biologiya - Agricultural biology. 2, 30-47. DOI 10.15389/AGROBIOLOGY.2018.2.309 [in Russian].

8. Baranova, N. S., Baranov, A. V., \& Podrechneva, I. Y. (2017). Geneticheskie osobennosti selekcii vysokoproduktivnyh korov zavodskih semejstv kostromskoj porody [Genetic features of selection of highly productive cows of the Kostroma cattle families]. Vestnik APK Verhnevolzh'ya - Agroindustrial Complex of Upper Volga Region Herald, Yaroslavl, 1 (37), 36-41 [in Russian].

9. Fedorovych, V. V., Orikhivskyi, T. V., Babik, N. P., Fedorovych, Ye. I., \& Oseredchuk R. S. (2016) Kharakterystyka koriv symentalskoi porody za hospodarsky korysnymy oznakamy v umovakh Lvivshchyny [Characteristics of Simmental cows by economically useful characteristics in the Lviv region]. Naukovyi visnyk Lvivskoho natsionalnoho universytetu veterynarnoi medytsyny ta biotekhnolohii imeni $S$. Z. Gzhytskoho - Scientific Bulletin of Lviv National University of Veterinary Medicine and Biotechnology. S. Z. Gzhytsky. Series: Agricultural Sciences. Lviv, 2 (67), 255-260. DOI 10.15421/NVLVET6756 [in Ukrainian].

10. Ryzhuk, S. M. (2014) Teoretyko-metodolohichni ta naukovo-orhanizatsiini aspekty stvorennia symentalskoi porody velykoi rohatoi khudoby (istorychnyi aspekt) [Theoretical-methodological and scientific-organizational aspects of creation of Simmental breed of cattle (historical aspect)]. Visnyk Natsionalnoho tekhnichnoho universytetu "KhPI" - The issue of National technical university "HPI". Kharkiv, 59, 124129 [in Ukrainian].

11. Araujo F. R., Vieira D. A., \& Santos D. J. (2020) Population structure of Simmental beef cattle using pedigree analysis. Tropical Animal Health and Production, 52, 1513-1517. DOI.ORG 10.1007/s11250-019-02102-x 
12. Perisic, P., Skalicki Z., \& Petrovic M. M. (2009) Simmental cattle breed in different production systems. Biotechnology in Animal Husbandry, 25, 315-326. DOI 10.2298/BAH0906315P.

13. Gotza, B., Luntza, J., Robeisa, C., Edela, R., Emmerlinga, J., Buitkampa, H., \& Anzenbergera J. (2015). Simmental cattle - Current state of the breeding program. Livestock Science, 179, 80-85.

ГЕНЕТИЧНА ДИФЕРЕНЦІАЦІЯ ЛІНІЙ СИМЕНТАЛЬСЬКОЇ ПОРОДИ ВЕЛИКОЇ РОГАТОЇ ХУДОБИ ЗА ПОЛІМОРФНИМИ СИСТЕМАМИ ГРУП KPOBI

Россоха В. І., Дробязко О. В, Бойко О. А., Тур Г. Н., Олійниченко Є. К., Задерихина О. А., Бровко О. В., Інститут тваринництва НААН.

Маркування популяиій великої рогатої худоби за окремими генами та комплексами генів, а також визначення на їх основі генотипової структури та рівня різноманіття, як структурних одиниць так і популяцій в цүілому, створюють передумови для розробки селекиійно - генетичних підходів, спрямованих на запобігання звуження генофонду популяцій та методів контролю і маркірування селекиійних процесів.

В статті надано результати досліджень генетичної структури популячії великої рогатої худоби симентальської породи ПАТ «Племінний завод «Червоний Велетень» за еритрочитарними антигенами 9 генетичних систем (A, $B, C, F, J$, $L, M, S, Z)$ з урахуванням лінійної належності тварин. Еритрочитарні антигени тварин визначали реакиією гемолізу з використанням моноспецифічних сироваток-реагентів.

Встановлено, що спектр визначених антигенів є характерним для симентальської худоби. Висока частота антигенних факторів $G_{2}, T_{2}, E_{3}^{\prime}, G^{\prime}, I^{\prime}, O^{\prime}, Q^{\prime}$, $B^{\prime \prime}(q=0,364$ - 0,636) дає підставу ідентифікувати алелі-маркери притаманні симентальській худобі: $B G K E^{\prime} G^{\prime} O^{\prime} Q^{\prime}, B G K E^{\prime} O^{\prime}, B G O^{\prime}, G_{2} O_{2} Y_{2}$, а також $O Q^{\prime}, O^{\prime} Q^{\prime}$, $T B^{\prime} P^{\prime}$.

Проведено аналіз структури найбільш чисельних заводських ліній: Неоліта, Лавра, Зоркого, Бісера, Ласкара. Показано, що маркерами лінії Неолита можна вважати алель $B^{\text {OI' }}(q=0,2931) \mathrm{ma} B^{\text {OTG } K^{\prime}}(q=0,2392)$, Лавра - $B^{\text {BIA }{ }^{\prime}}$ $(q=0,1863) m a B^{O^{\prime}}(q=0,2500)$, Зоркого - $B^{B G O}(q=0,1325) m a B^{b}$, Бісера $-B^{\text {OIQ }}$ $(q=0,2246) m a B^{G /}(q=0,1920)$, Ласкара - $B^{B G K E^{\prime} O^{\prime} Q^{\prime}}(q=0,1405) \mathrm{ma} \mathrm{B}^{O^{\prime}}(q=0,2735)$.

Встановлено, щу за алелям ЕАВ - системи груп крові найбільшою подібністю відзначаються лінії Лавра та Ласкара $\left(K_{6}=32,04 \%\right)$, найвищі значення коефіцієнта відмінності характерні для ліній Неоліта - Ласкара та Неоліта - Лав-

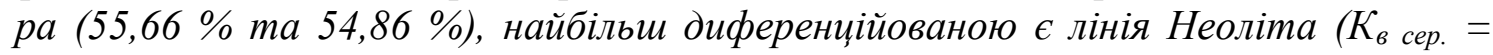
$\left.49,48 \%, d_{\text {cep. }}=0,332\right)$.

Виявлення міжлінійних відмінностей у споріднених групах симентальської худоби дає можливість попереднього прогнозування, корекиї та планування добору тварин для заводських парувань.

Ключові слова: еритрочитарні антигени, поліморфні системи груп крові, частота антигенів, генетична диференціація, велика рогата худоба, симентальська порода, лінія. 


\section{ГЕНЕТИЧЕСКАЯ ДИФФЕРЕНЦИАЦИЯ ЛИНИЙ СИММЕНТАЛЬСКОЙ ПОРОДЫ КРУПНОГО РОГАТОГО СКОТА ЗА ПОЛИМОРФНЫХ СИСТЕМАМИ ГРУПП КРОВИ}

Россоха В. И., Дробязко О. В., Бойко Е. А., Тур Г. Н., Олейниченко Е. К., Задерихина Е. А., Бровко А. В., Институт животноводства НААН

Маркировка популяциий крупного рогатого скота по отдельным генами и комплексам генов, а также определение на их основе генотипической структуры и уровня разнообразия, как структурных единии, так и популяций в целом, создают предпосылки для разработки селекционно - генетических подходов, направленных на предотвращение сужение генофонда популяичй и методов контроля и маркировки селекционных процессов.

В статье даны результаты исследований генетической структуры популяции крупного рогатого скота симментальской породы ОАО «Племенной завод «Красный Великан» по эритроиитарными антигенами 9 генетических систем (A, $B, C, F, J, L, M, S, Z)$ с учетом линейной принадлежности животных. Эритроцитарные антигены животных определяли реакцией гемолиза с использованием моноспецифических сывороток - реагентов.

Установлено, что спектр определенных антигенов характерен для симментальской породы. Высокая частота антигенных факторов $G_{2}, T_{2}, E_{3}{ }^{\prime}, G^{\prime}, I^{\prime}, O^{\prime}$, $Q^{\prime}, B^{\prime \prime}(q=0,364$ - 0,636) дает основание идентифиџировать аллели-маркеры присущи симлентальскому скоту: $B G K E^{\prime} G^{\prime} O^{\prime} Q^{\prime}, B G K E^{\prime} O^{\prime}, B G O^{\prime}, G_{2} \mathrm{O}_{2} Y_{2}$, а также $O Q^{\prime}, O I^{\prime} Q^{\prime}, T B^{\prime} P^{\prime}$.

Проведен анализ структуры наиболее многочисленных заводских линий: Неолита, Лавра, Зорко, Бисера, Ласкара. Показано, что маркерами линии неолита можно считать аллели $B^{\text {OIQ }} "(q=0,2931)$ и $B^{\text {OTG } K^{\prime}}(q=0,2392)$, Лавра - ${\text { BIA } K^{\prime}}^{\prime}$ $(q=0,1863)$ и $B^{O^{\prime}}(q=0,2500)$, Зоркий - $B^{B G O}(q=0,1325)$ и $B^{b}$, Бисера - $B^{\text {Or } Q^{\prime}}(q=$ $0,2246)$ и $B^{G \prime}(q=0,1920)$, Ласкара - $B^{B G K E^{\prime} G O^{\circ} Q^{\prime}}(q=0,1405)$ u $B^{O^{\prime}}(q=0,2735)$.

Установлено, что при аллелях ЕАВ - системы групп крови сходством отмечаются линии Лавра и Ласкара $\left(K_{6}=32,04 \%\right)$, высокие значения коэффиџиента различия характерны для линий неолита - Ласкар и Неолита - Лавра (55,66\% и $54,86 \%$ ), наиболее дифференцированной является линия неолита ( $K_{6}$ сер. = $49,48 \%, d_{\text {cep. }}=0,332$ ).

Выявление межлинейных различий в родственных группах симментальской породы дает возможность предварительного прогнозирования, коррекиии и планирования отбора животных для заводских спариваний.

Ключевые слова: эритрочитарные антигены, полиморфные системы групп крови, частота антигенов, генетическая дифференщиащия, крупный рогатый скот, симментальская порода, линия. 